\title{
THE IROQUOIS PIPELINE PROJECT: A STUDY IN FEDERAL/STATE CONFLICT
}

\author{
FREDERICK M. LOWTHER*
}

In this paper, the author reviews the genesis of the Iroquois Pipeline Project, outlines the regulatory authorization process, and discusses the construction of the pipeline and conflicts which arose in New York and Connecticut, prior to and during construction. He then analyzes the litigation arising in the aftermath of construction, specifically the National Fuel decision, as well as future regulatory control over the pipeline.

\section{TABLE OF CONTENTS}

I. INTRODUCTION $\ldots \ldots \ldots \ldots \ldots \ldots \ldots \ldots \ldots \ldots \ldots$

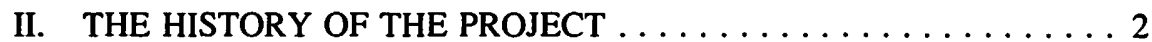

III. THE REGULATORY PROCESS FOR IROQUOIS: PRECURSOR TO THE FEDERAL/STATE CONFLICT $\ldots \ldots \ldots \ldots \ldots \ldots \ldots \ldots \ldots \ldots \ldots \ldots \ldots$

IV. THE NATIONAL FUEL DECISION: THE SHOT THAT STARTED THE WAR $\ldots \ldots \ldots \ldots \ldots \ldots \ldots \ldots$

V. CONSTRUCTION OF THE PIPELINE: THE MAIN

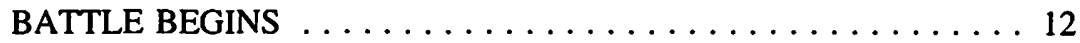

VI. CONTINUATION OF THE FEDERAL LITIGATION AND THE COMMENCEMENT OF STATE

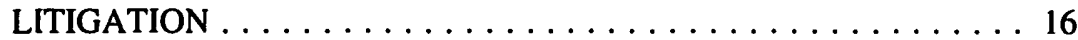

VII. FEDERAL PREEMPTION UNDER THE NATURAL GAS ACT AND THE RELATED ISSUES OF RETROACTIVITY, WAIVER

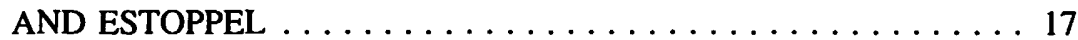

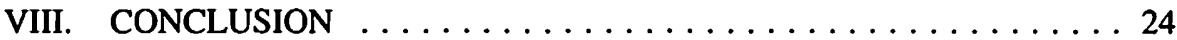

\section{INTRODUCTION}

The development, certification and construction of the Iroquois Pipeline Project (hereinafter the "Iroquois Project" or the "Project" or "Iroquois") is one of the greatest legal and engineering achievements of the decade. The Project involved the construction of a 380 mile high pressure natural gas pipeline system from the U.S.-Canada border near Iroquois, Ontario, through the the State of New York, through the southwestern corner of the State of Connecticut, across Long Island Sound, and terminating on Long Island at the western end of the New York Facilities System serving the Greater New York City Metropolitan area. While the Project standing alone as a U.S. pipeline system is impressive in scope, the true significance of the Project is the link it provides to a dramatically expanded Canadian pipeline system, originating in Western Canada and

Mr. Lowther is a partner in the Washington, D.C. law firm of Dickstein, Shapiro \& Morin. Mr. Lowther is also General Counsel to the Boundary Gas Project and Alberta Northeast Gas Limited. Mr. Lowther has served as Project Counsel to the Iroquois Pipeline Project since its inception in 1985. 
operated by TransCanada PipeLines Limited ("TransCanada"). All told, the TransCanada expansion and the Project involved the expenditure of more than $\$ 2$ billion. The intended purpose, and the great achievement, of the Project was a flexible, competitive connection between the fast growing market for natural gas in the U.S. Northeast and the vast natural gas reserves of Western Canada. For anyone with even a rudimentary understanding of energy markets and the concept of energy security, the strategic importance of the Project is readily apparent.

No one could ever have doubted the complexity of an undertaking of this scope. In a continent characterized by intense economic and environmental regulation as well as intense competition in the energy sector, the Project sponsors recognized from the outset that obtaining governmental authority to construct, acquiring the right-of-way and actually constructing a 380 mile utility corridor through some of the most densely populated, environmentally sensitive lands in North America would require time and perseverance, not to mention money. However, what the Project sponsors had not contemplated, and to this day still cannot fathom, was the bitter conflict which the Project evoked between competing "jurisdictional" interests of the U.S. Federal government and the governments of the affected states (most notably New York). It was that conflict which turned a Project of which those involved could be proud, into at best a baffling, and at worst a bitter, experience.

This article focuses primarily on the genesis of the Federal/state conflict and on the legal principles over which that battle has been fought.

\section{THE HISTORY OF THE PROJECT}

The origin of the Iroquois Project is itself a subject for a long article, which will no doubt be written when the time is ripe. Here, only the briefest of summaries is necessary.

The decade of the 1970's was a difficult one for the natural gas industry, particularly the local gas distribution companies ("LDCs") which served as the link between the producing and pipeline sectors of the industry and the natural gas user. The 1970's began as a period of shortages. At a time when the prices of crude oil and oil product were skyrocketing due (initially) to the 1973 Arab Oil Embargo, the U.S. government insisted on maintaining a system of regulation which kept the price of natural gas artificially low. As a consequence, little money was being invested in replenishing natural gas reserves at a time when low prices, and other advantages of natural gas, were causing a surge in demand. The result was severe and economically destructive periods of curtailment. For LDCs in particular, curtailments were extremely troublesome, placing extraordinary pressures on load management and effectively requiring LDCs to stop growing their markets. In what would later become one of the great legislative ironies, the Congress even passed laws restricting the use of natural gas for production of electric power.'

I. See, e.g., the Powerplant and Industrial Fuel Use Act of 1978, P.L. 95-620 (1978), which placed severe restrictions on use of natural gas under new and even existing power plant boilers. The irony is that, today, the power generation market is one of the fastest growing markets for natural gas, and in areas like the U.S. Northeast, it is the power generation market which creates the opportunity for 
By the mid-70's, the government was awake to the fact that its regulatory policies were responsible for the massive imbalance between gas supply and demand. By 1978, many of the key restrictions on the price of natural gas at the wellhead had been removed and prices began to rise rapidly to (and eventually above) market-clearing levels. Having undergone years of turmoil caused by a shortage of gas supplies, the pipelines which, at that point, were responsible for purchasing gas for resale to LDCs, went on a buying binge, entering into countless contracts for long-term gas supplies. Most of those contracts included the now infamous "take or pay" clauses which provided producers the economic assurances they needed to invest money in establishing new reserves. Although, with hindsight, the adverse consequences of binge-buying in combination with take or pay clauses should have been predictable, few had the necessary foresight, let alone the power, to stop the trend.

Among the few companies which did have foresight was a group of LDCs in the U.S. Northeast, led both in spirit and in fact by The Brooklyn Union Gas Company ("Brooklyn Union"). Brooklyn Union and a handful of other Northeast LDCs understood that the only way they could protect themselves from the shortage-to-surplus pendulum was to begin reducing their (at the time almost total) dependence on the interstate pipelines for long-term gas supplies. As a practical matter, that meant entering into contracts with stable producers to buy significant quantities of gas directly.

The direct purchase strategy of the Northeast LDCs faced three obstacles: opposition from the interstate pipelines and producers (who were counting on the LDCs to buy the gas for which the pipelines had entered into take or pay contracts); identification of sellers willing to enter into price-competitive, long term contracts; and negotiation of contracts for the transportation of the direct-purchase gas to the LDCs' city gates. Ultimately, the last obstacle, transportation, proved to be the most difficult.

The process of identifying a source of direct-purchase gas was somewhat tumultuous. Ultimately, Western Canadian producers (acting through what was then their principal seller, TransCanada) stepped forward and agreed to enter into price-flexible, long term contracts with Brooklyn Union and, by then, an expanding number of Northeast LDCs. The first manifestation of this arrangement was the "Boundary Gas Project," which was born in early 1980 .

The fight to overcome pipeline and producer opposition took place in the U.S. and Canadian regulatory proceedings in which TransCanada sought authorization to export the Boundary Gas Project volumes to the U.S. buyers, and the U.S. buyers sought authorization to import the volumes. That fight took place from 1980 through 1984, and involved countless days of hearings and millions of pages of legal pleadings. The battle, however, was successful and the export and import of the Boundary volumes on a direct-purchase basis was approved in both Canada and the United States. 
The process of arranging transportation for the direct-purchase gas was the most complicated aspect of the direct-purchase initiative. After determining that Canadian gas supplies were available for direct purchase, the Northeast LDCs approached their traditional U.S. interstate pipeline suppliers and requested their cooperation in moving the gas to market. With a lone exception, the response was very simple: No! The exception was Tennessee Gas Pipeline Company ("Tennessee"), whose enlightened management recognized that, ultimately, there was more to be gained by cooperation with the move toward direct LDC gas purchases. Thus, in 1980, when the Boundary Gas Project was launched, Tennessee and the LDCs became allies in what proved to be a long battle for authorization of the Boundary Gas Project.

When final authorization of the Boundary Gas Project was granted in $1984,{ }^{2}$ the interstate pipelines serving the Northeast market decided that, having lost the legal battle to prevent direct gas purchases by LDCs, they would be well-advised to attempt to control the move toward direct purchases by LDCs. Thus, when the LDCs undertook to expand the Boundary Gas Project, the LDCs found a "new attitude" among the interstate pipelines. Specifically, the two main opponents of the Boundary Gas Project, Transcontinental Gas Pipe Line Corporation ("Transco") and Texas Eastern Transmission Company ("Texas Eastern"), joined with Tennessee and TransCanada to develop a new delivery system linking the TransCanada pipeline system in Eastern Canada to the Transco, Texas Eastern and Tennessee systems serving the Northeast LDCs. The new "link" was called the Niagara Interstate Pipeline System or "NIPS." NIPS was billed as the solution to the LDCs' transportation problems, theoretically giving the Northeast LDCs virtually unrestricted access to gas supplies purchased directly (and by the interstate pipeline sponsors themselves) from Canada.

The impression that the transportation obstacle to LDC direct purchases had been overcome persisted for only a short time. Without regard to who was to blame, the NIPS project quickly stalled. By mid-1985, when the Northeast LDC sponsors of the Boundary Gas Project (by that time numbering fifteen companies) had begun in earnest the regulatory proceedings to expand the project from $40 \mathrm{MMcf} / \mathrm{d}$ to nearly $300 \mathrm{MMcf} / \mathrm{d}$, it was relatively clear that the NIPS system would never be built. Worse yet, there was some evidence that the delays and confusion surrounding the NIPS project may have been a deliberate effort by one or more or the NIPS sponsors to frustrate the introduction of more direct purchase gas into the Northeast market.

Sensing that the NIPS project was not going to be the solution to the transportation bottleneck for direct purchase gas, and that, while the NIPS project was undergoing its death throes, the pipeline sponsors would not be likely to enter into contracts to transport Boundary Gas Project volumes "around" the NIPS project, a group of the LDC sponsors of the Boundary Gas Project met in August 1985 at the offices of Brooklyn Union in Brooklyn, NY to examine alternatives. Given the five year history of opposition from the interstate pipelines (with the exception of Tennessee), and the additional fact that 
Tennessee was now entangled in the NIPS project, the LDCs quickly concluded that there was only one solution - build their own pipeline system.

The problems associated with a group of LDCs striking out on their own to construct a new interstate pipeline system to bring Canadian gas into the heart of their interstate pipeline suppliers' Northeast market were mind-boggling. Indeed, the consensus at the meeting (at which the author was present) was that the undertaking might well be impossible to accomplish. Nonetheless, the upsides of the concept were so enormous (including the opportunity to design a pipeline system specifically tailored to the needs of the Northeast market) that a decision was made to begin moving forward.

The LDC group quickly recognized that it did not have the financial or technical wherewithal to achieve such a massive project on their own. The key to the success of the idea was to get TransCanada on board, and to make the pipeline a 50.50 U.S.Canadian joint venture. It did not take long for TransCanada to recognize the merits of such a project, and in the fall of 1985, TransCanada, five Northeast LDCs and a Bostonbased energy project developer (J. Makowski Associates, Inc.), entered into an agreement to determine the feasibility of what would eventually become the Iroquois Project.

As one might imagine, when the study group announced in late 1985 that they were examining the feasibility of a new, north-to-south pipeline system to link the TransCanada system with the Northeast market, they were met with a combination of laughter and tough talk. The idea was viewed by some as downright crazy; it was viewed by others as an out-and-out threat to the pipelines already serving the market. The key variable, however, was not how the pipeline competitors viewed the idea; it was how the Federal and state governments viewed the idea. As anxious as the study group was to accomplish the project, they knew that it could not succeed without political support and without a consensus among Federal and state regulators that a project of such monumental proportions had a fighting chance of success.

By early 1986, it was clear to the study group that Federal and state political support was sufficient to warrant a finding of feasibility. By March 1986, agreement had been reached among the project sponsors on a general route for the pipeline; key financial advisors had pronounced the project financeable; and knowledgeable industry observers had declared that, although extremely difficult, it would be physically possible to acquire the right-of-way to place such a pipeline in the "back yards" of the people in New York and Connecticut. Thus, in March 1986, a name was selected - Iroquois Gas Transmission System - and on May 30, 1986, an application for a certificate of public convenience and necessity under section 7(c) of the Natural Gas Act of $1938,{ }^{3}$ was filed with the Federal Energy Regulatory Commission ("FERC").

15 U.S.C. $\$ 717$ et seq.

By the time the Iroquois FERC application was filed, the project to import the Canadian gas supplies which would be transported by lroquois had undergone a significant expansion and was renamed the Alberta Northeast Gas Limited, or "ANE" project. With the formation of the ANE Project in late 1985, the Boundary Gas Project became limited to the volumes authorized for export/import under that name, 10 wit $92.5 \mathrm{MMcf} / \mathrm{d}$. 


\section{THE REGULATORY PROCESS FOR IROQUOIS: PRECURSOR TO THE FEDERAL/STATE CONFLICT}

From the very outset, the Iroquois Project sponsors were confronted with a potential conflict between Federal and state governmental authorities. It had long been clear, by virtue of two key U.S. Supreme Court decisions, Northern Natural Gas Co. v. Comm'n of the State of Kansas, ${ }^{5}$ and Schneidewind v. ANR Pipelines Co., ${ }^{6}$ that the Natural Gas Act preempted state law with regard to regulation of interstate natural gas pipeline facilities. Under the Northern Natural and Schneidewind precedents, Iroquois would theoretically have been able to construct and operate the Iroquois system without any permits or authorizations under state law. However, notwithstanding those precedents, there were two aspects of Federal regulation which Iroquois had to evaluate in deciding how to proceed vis a vis state regulatory bodies. The first aspect was the fact that the FERC regulations governing interstate pipeline construction specified a number of state permits which had to be obtained by an applicant as a condition precedent to receipt of a FERC certificate. The primary areas to which these regulations were directed were stream, river and wetland crossings, as well as areas of particularly local concern, such as state and local highway crossings. The second aspect was the fact that two Federal laws, section 40 of the Federal Clean Water $\mathrm{Act}^{7}$ and the Coastal Zone Management $A c t,{ }^{8}$ require any applicant for a Federal license or permit (such as a FERC certificate) to file with the permitting agency (in this case FERC) a certification that the Federally authorized activity will be consistent with state water quality laws and coastal zone management plans in the states where construction will occur. As with state stream, river and wetland crossing permits, the section 401 water quality and coastal zone consistency certifications were conditions precedent to construction pursuant to the FERC certificate. The key question and the one which ultimately gave rise to the Federal/state conflict affecting the Iroquois Project, was whether, once conditions precedent were satisfied and the FERC certificate was issued, the states issuing the permits and certifications could use those authorizations to exercise continuing regulatory control over the pipeline. It had always been clear that it was not FERC's intention to cede regulatory power to state and local governments by requiring state and local permits. 9 The question was whether,

s. $\quad 372$ U.S. 84, 83 S. Ct. 646, 9L Ed. 2d 601 (1963) [hereinafter "Northern Natural"].

6. 485 U.S. 293, 10 S. Ct. 1145 (1988) [hereinafter "Schneidewind"].

7. 33 U.S.C. $\$ 1341$.

8. 16 U.S.C. $\$ \S 1451-1464$.

9. FERC clarified its intention in this regard in a recent order on rehearing in the Iroquois docket. There, FERC stated:

The Commission and the courts have addressed the extent to which federal law preempts state and local law in connection with the issuance of certificates... [citing the National Fuel decision, discussed in detail infra]. Although the Natural Gas Act and the regulations promulgated by the Commission pursuant to that statute generally preempt state and local law, the Commission has encouraged applicants to cooperate with state and local agencies with regard to the siting of pipeline facilities, environmental mitigation measures, and construction procedures.... However, the Commission's practice of encouraging cooperation between interstate pipelines and local authorities does not mean that those agencies may undermine, through their regulatory requirements, the force and effect of a certificate issued by this Commission.

Order on Rehearing, FERC Docket No. CP91-2677-001 et al. (April 28, 1992). 
despite FERC's intention, the requirement to obtain state and local permits had the legal effect of transferring power.

Unaware that the Iroquois Project would become a battleground over Federal versus state jurisdiction, the Iroquois sponsors, in 1986, evaluated the most efficient means of obtaining the state permits and certifications required as conditions precedent to the FERC certificate. Because the problems experienced with the State of Connecticut were typical of the state regulatory problem in general and because the principal fight over jurisdiction occurred with the State of New York, the remainder of this article will focus exclusively on the State of New York. Indeed, to the extent that there was jurisdictional tension between Iroquois, the Federal government and the State of Connecticut, all parties were able to resolve their differences without resort to litigation in Federal or state court. Thus, the focus of discussion on the problems with the State of New York is appropriate.

In evaluating the best approach to obtaining State of New York permits and certifications, Iroquois initially had a choice between two procedures. The first procedure was denominated the "SEQRA process," so named because it was specified by the State Environmental Quality Review Act. ${ }^{10}$ Under the SEQRA process, Iroquois would have applied for stream, river and wetland crossing permits from the local jurisdiction in which the specific stream, river or wetland existed; it would have applied for highway crossing permits from local authorities at the site of the crossing, etc. However, because the Project was so massive and covered so many counties and local political jurisdictions, the SEQRA process would be overseen and coordinated by the State of New York Department of Environmental Conservation ("DEC"). In addition, the section 401 water quality certification would have been issued by DEC directly; the coastal zone management plan certification would have been issued by the New York Department of State. The obvious drawback to the SEQRA process was the need to file and coordinate applications with literally several hundred local authorities (there being more than 600 stream crossings alone in the State of New York).

The second alternative was the so-called "Article VII process," so named because it was specified in Article VII of the New York Public Service Law." The Article VII process was billed by the state as a "one-stop shopping" process under which all state and local permits could be obtained in a single proceeding, conducted under the auspices of the New York State Public Service Commission ("NYPSC"). The advantages of "onestop shopping" were obvious; the only major drawback appeared to be that only one interstate pipeline had ever submitted itself to the Article VII process (in that case for a short pipeline extension) and thus there was little actual experience on how the process would work. There was, therefore, the danger that the NYPSC-controlled proceeding would present significant procedural difficulties. Unfortunately, this danger became a reality. More importantly, there was a concern, which ultimately proved to be legitimate, that submitting to so comprehensive a process as Article VII would lead to confusion, if 
not actual conflicts, between the scope of state and Federal control over the Iroquois Project.

While Iroquois debated the relative merits of the two different approaches to state permits and certifications, the decision was literally taken out of Iroquois' hands. In the fall of 1986, DEC advised Iroquois that the legislature had not appropriated sufficient funds for DEC to oversee a SEQRA process for an undertaking as complex as the Iroquois Project. Shortly thereafter, the NYPSC announced that New York would, starting with the Iroquois Project, require all interstate pipelines to obtain state and local permits and certifications using the Article VII process. Accordingly, in December 1986, Iroquois filed its application with the NYPSC seeking an Article VII "certificate of environmental compatibility and public need" as a means of obtaining the state authorizations required under Federal law. In submitting to the Article VII process, Iroquois was very careful to state in the preamble to its application that:

The information contained in this Application is based on data contained in [Iroquois'] May 1986 application for a certificate of public convenience and necessity pursuant to Section 7(c) of the Natural Gas Act, as amended, and the [FERC] regulations... authorizing the construction and operation of the proposed pipeline.... In seeking a certificate from the PSC, it is [Iroquois'] intent to fulfill the FERC requirement that state and local concerns be addressed in conjunction with the federal certificate process.

This statement was intended to signal both to the NYPSC and to FERC that, in seeking an Article VII certificate, Iroquois was not submitting to state jurisdiction in any way which would conflict with Iroquois' overriding obligations under the preemptive FERC certificate.

Immediately upon receipt of Iroquois' Article VII application, the NYPSC scheduled "public notice" hearings and then convened evidentiary hearings which would continue for almost three years. While Iroquois' objective in undertaking the Article VII process was to obtain the state permits and certifications predicate to its FERC certificate, the Article VII proceeding initiated and carried on by the NYPSC was a full-blown certificate proceeding, not limited to particular permits and certifications. In other words, no specific recognition was given by the NYPSC to the limited purpose of the Iroquois Article VII proceeding. As a consequence, Iroquois and its prospective shippers in New York were required to demonstrate that there was a "public need" for the Iroquois Project and for the gas supplies which it would deliver to New York LDCs.

At the same time that the NYPSC Article VII proceeding was in progress, Iroquois was fully engaged in the FERC certificate proceeding. The overlap between the NYPSC and FERC processes, especially on the issues of "need" and site-specific environmental review, was extensive. As it ultimately turned out, the Final Environmental Impact Statement ("FEIS") issued by the FERC for the Iroquois Project was one of the most extensive ever prepared for a pipeline project. Notwithstanding the unusually broad scope 
of the FERC environmental inquiry, the NYPSC Article VII proceeding continued to delve deeply into the same issues. ${ }^{12}$

Despite the overlap and duplication between the NYPSC Article VII and FERC processes, Iroquois viewed the situation as costly and burdensome but not as a precursor of future problems. Iroquois' perspective, reflected in numerous legal filings, was that Iroquois was simply discharging its obligation to cooperate with state regulatory authorities in the process of obtaining its FERC authorizations.

The Iroquois NYPSC Article VII proceeding resulted in Opinion No. 89-42 ("Opinion 89-42") issued by the NYPSC on December 8, 1989, which granted Iroquois a certificate of environmental compatibility and public need and a section 401 water quality certification. Notwithstanding a recommendation to the contrary by the two administrative law judges conducting the Article VII evidentiary hearings, the NYPS certificate did not include a coastal zone consistency determination; that certification ultimately had to be obtained separately from the New York Department of State. In any event, between the Article VII certificate and the Department of State coastal zone consistency determination, Iroquois had by September 1990 satisfied the FERC requirement that Iroquois obtain certain state and local permits and certifications in the State of New York. Iroquois so advised FERC, paving the way for final action on the FERC certificate.

Under the terms of the NYPSC Article VII certificate, Iroquois had a continuing obligation to the NYPSC in the form of a requirement that Iroquois file (and receive NYPSC approval of) construction drawings for the pipeline. These filings, designated Environmental Management \& Construction Plans ("EM\&CPs"), were in effect the detailed drawings and construction specifications which would have been necessary in any event for a project of this nature. Accordingly, no special legal significance was attached by Iroquois to the requirement for approval of the EM\&CPs by the NYPSC. Ultimately, the pipeline had to be built to the rigorous specifications set forth in the FERC FEIS and section 7(c) certificate and applicable Federal regulations and, on their face, the EM\&CPs would not present any inherent conflict since they would reflect the FERC specifications. Iroquois did not realize at the time, although perhaps it should have, that the EM\&CPs would be the device through which the NYPSC would seek to assert regulatory control over the pipeline.

As it was required to do, Iroquois formally accepted the NYPSC Article VII certificate on January 4, 1990. In doing so, Iroquois was extremely careful to state in its verified statement that its acceptance was:

subject to... any valid provisions or federal law and of any federal authorizations granted to Iroquois for the pipeline project authorized herein.

12. In addition to the NYPSC Article VII and FERC proceedings, Iroquois was also engaged in proceedings before the U.S. Army Corps of Engineers to obtain permits under section 10 of the Rivers and Harbors Act of 1899, 33 U.S.C. \$ 403, and section 404 of the Clean Water Act, 33 U.S.C. $\$ 1344$. The Corps of Engineers process operated in tandem with the FERC process, and therefore this article does not dwell on the Corps of Engineers aspects of the Federal/state conflict. 
By that statement, Iroquois intended to preserve the preemptive effect of the Natural Gas $A c t$, and to protect itself against any conflicting requirements of state law.

\section{THE NATIONAL FUEL DECISION: THE SHOT THAT STARTED THE WAR}

On January 14, 1990, just ten days after Iroquois had accepted its NYPSC Article VII certificate, the U.S. Court of Appeals for the Second Circuit - which is the Federal circuit covering the States of New York and Connecticut - rendered its decision in National Fuel Gas Supply Corp. v. Public Service Commission. ${ }^{13}$ The National Fuel case involved a dispute between National Supply Corp. ("National Fuel") and the NYPSC over whether National Fuel was required to apply for and secure an Article VII certificate from the NYPSC prior to constructing a small (less than 10 mile) replacement loop on its existing interstate system in New York. National Fuel refused to apply for the Article VII certificate, claiming that Article VII was preempted by the Natural Gas Act and that, to the extent that FERC required National Fuel to obtain state or local permits for the small loop, it could do so in an alternative fashion. When the NYPSC threatened action against National Fuel, the company sought a declaratory judgment in Federal District Court that the attempt to impose the Article VII requirement was invalid under the principles of preemption established in the Schneidewind and Northern Natural cases.

National Fuel lost the case at the District Court level and appealed to the Second Circuit Court of Appeals (all of which was taking place while Iroquois was busy progressing through the Article VII process before the NYPSC). In a clear and resounding decision, the Second Circuit Court of Appeals reversed the District Court, held that the preemption principles of Schneidewind and Northern Natural governed regulation of interstate pipelines and held that the NYPSC could not impose the Article VII process on National Fuel or penalize National Fuel for constructing its pipeline loop without an Article VII certificate. The specific reference in the National Fuel decision to monetary penalties as representing the "imminent possibility of conflict" which justified preemption, ${ }^{14}$ was indeed a precursor of what was to befall Iroquois.

In Constitutional parlance, the holdings of National Fuel and of the two predecessor cases, Schneidewind and Northern Natural, established a principle known as "field preemption" for the Natural Gas Act. Under the doctrine of "field preemption," the Congress (in this case, through the Natural Gas Act and other Federal statutes ${ }^{15}$ ) has decreed that the Federal government has fully occupied the field of regulating the rates and facilities of interstate natural gas pipelines, leaving no room for state regulation. Thus, under the doctrine reaffirmed by National Fuel, the NYPSC had no independent power to regulate the Iroquois pipeline. The fact that the FERC promulgated regulations which required Iroquois, indeed all interstate pipelines, to obtain certain state and local

894 F.2d 571 (2nd Cir. 1990), cert. denied, 110 S. Ct. 3240 [hereinafter "National Fuel"]. 894 F.2d 571 at 577.

The "comprehensive scheme of Federal regulation," as the Supreme Court called it Northern Natural, includes, most notably, the Natural Gas Policy Act of 1978, P.L. 95-621, and the Natural Gas Pipeline Safety Act of 1968, P.L. 90-481. 
permits as a condition precedent to FERC certification was not inconsistent with field preemption. The FERC was not intending to and indeed could not have ceded regulatory power to the states. Instead, FERC was merely securing state input into the Federal certification process. This purpose was expressly discussed in the National Fuel decision itself, where the Court pointed out that any complaint by the NYPSC that National Fuel was not complying with the requirements of FERC regulations with regard to state permits should be addressed, not to National Fuel in the form of penalty threats, but to the FERC, whose certification process it is. ${ }^{16}$

Iroquois' reaction to the National Fuel decision was that the law had not changed and that, from Iroquois' perspective, its Article VII certificate remained valid as the chosen means of securing the state and local permit and certifications required by FERC regulation.

Notwithstanding Iroquois' position on the National Fuel decision, one of the inveterate opponents to the Project filed a letter-motion with the NYPSC seeking a determination that National Fuel had declared the Article VII process unconstitutional, and that the Iroquois Article VII certificate was therefore invalid and of no further force and effect. Presumably, the intention of the motion was to eliminate the state and local permits embedded in Iroquois' Article VII certificate, thus (theoretically) eliminating an essential predicate for issuance of a FERC certificate to Iroquois.

Iroquois opposed the motion to vacate the Article VII certificate, on the following grounds:

[T] The National Fuel decision does not support Mueser's claim that the [NYPSC's Article VII] certificate is "without lawful force and effect".... While it has been recognized throughout this case that FERC's ultimate decision will have preemptive effects regarding the [NYPSC's] Opinion, the National Fuel decision recognizes that FERC may require federal applicants to secure certain state permits. (National Fuel [894 F.2d at 579]). To the extent that Iroquois is required by federal law to obtain state and local permits (or a waiver of restrictive local ordinances), the "one-stop" Article VII process invoked by Iroquois to satisfy such federal requirements, and the certificate granted thereunder, clearly are and will be of valid force and effect. It is equally clear that without a FERC certificate and compliance with its conditions, Iroquois may not commence construction of the pipeline project as contemplated by its Article VII certificate or otherwise. Thus, Mueser's request for recision of the Article VII certificates or a stay of Opinion 89-42 are entirely unnecessary and unwarranted, and should be rejected by the Commission.

A footnote to this section of Iroquois' Response cross-referenced two earlier footnotes, which stated:

The preemptive effects of FERC's ultimate decision on Iroquois' application and regulation of Iroquois have been known, recognized, and accommodated throughout this proceeding.... 
As reflected in Iroquois' January 4, 1990 acceptance of the Article VII certificate, Iroquois neither can nor wishes to relieve itself of FERC regulation or certificate requirements, or to avoid supervening requirements of federal law....

On April 30, 1990, the NYPSC issued Opinion No. 89-42A denying the motion seeking recision of Iroquois' Article VII certificate. In that Opinion, the NYPSC agreed with Iroquois' assessment, stating that:

although we have always recognized that the final determination as to need and routing of the pipeline would lie with FERC, we perceived no prohibition against reviewing the project in the first instance, consistent with our responsibility for issuing state and local permits still required by federal law even after [National Fuel].

At this point in the regulatory process, it seemed that Iroquois, the NYPSC and FERC were reading from the same script and that the desired circumstance of having Federal and state authorities acting in concert had been achieved. That perception appeared to be confirmed on June 1, 1990, when FERC issued the FEIS for Iroquois. It was further confirmed on July 30,1990 , when FERC issued its first "preliminary" order, ${ }^{17}$ indicating that it intended to certificate the Iroquois Project, subject to resolution of an outstanding request for a limited hearing on selected points (which hearing was granted and held in August 1990). It was finally confirmed, or appeared to be, when FERC, on November 14, 1990, issued its final Order No. 357 certificating the Iroquois Project. ${ }^{18}$

While Iroquois was completing the FERC process leading to its certificate, it was also completing the process of filing and obtaining approvals of the EM\&CPs required by the NYPSC Article VII certificate. Although copies of the EM\&CPs were filed with the FERC, the standards ultimately governing construction were those established by FERC in the FEIS and its certificate, and the EM\&CPs could only be valid to the extent that they were consistent with the FERC standards. To underscore this point, Iroquois' FERC certificate included a condition which required written construction clearance for each mile of pipeline construction, before construction on that mile could begin. The process of obtaining those construction clearance letters from FERC's Office of Pipeline and Producer Regulation ("OPPR") was a tedious one, requiring demonstration that each and every condition precedent in the FEIS and FERC certificate had been satisfied.

\section{CONSTRUCTION OF THE PIPELINE: THE MAIN BATTLE BEGINS}

The Iroquois construction program began in March 1991 with construction of the 26 mile, complex crossing of Long Island Sound. The Sound was one of dozens of examples of construction segments which were subject to environmentally driven "construction windows," periods within which construction could occur and beyond which construction was forbidden or severely restricted. Iroquois' entire construction schedule was driven 
by these "windows," which included "windows" on crossings of sensitive streams (e.g., trout spawning streams).

Construction of the Long Island Sound crossing was accomplished with minimal involvement by NYPSC officials. However, when Iroquois commenced the land-based construction process in upstate New York, the picture changed dramatically. Within days of commencing clearing and grading in upstate New York in April/May 1991, it appeared that the NYPSC inspectors overseeing construction on behalf of the NYPSC had been instructed to play an active day-to-day role in determining what could and could not be done by the Iroquois construction contractors. While Iroquois was prepared to accept "oversight" to assure that conditions agreed to during the Article VII process were met, it was not prepared to live with the NYPSC inspectors' "interpretations" of certain conditions. Iroquois was even less prepared to accept what ultimately became the NYPSC's hard line position, namely that it had authority to change the applicable requirements in the middle of construction, in effect regulating and controlling key elements of the construction process.

Examples of the attempts by the NYPSC to impose new conditions on construction are virtually countless. For purposes of this article, however, there is one incident which stands out and will stand forever in the annals of pipeline construction as an extreme example of governmental intrusion. The incident is widely known as the "Wappinger Creek Incident" because it occurred at a small creek (roughly 80 feet across) in mid-state New York.

By way of background, Wappinger Creek is classified as a sensitive trout stream by the State of New York and was the subject of much debate in routing the pipeline. Iroquois' originally proposed routing would have seen the pipeline cross Wappinger Creek once. However, by the time the NYPSC and FERC had taken into account all comments from landowners and agencies in the area, the FERC-approved routing involved three crossings of Wappinger Creek.

Under the FERC certificate and the FEIS, the approved method for crossing Wappinger Creek was the so-called "wet method," in which the pipeline trench was dug in the flowing stream, using segments of pipe called "flumes" to transport flowing water from the upstream to the downstream side of the open trench. The pipeline was then installed immediately, before the trench could fill in. The advantage of the wet crossing method was speed: a stream like Wappinger could be crossed in a matter of hours, minimizing the period of disturbance to the stream. The alternative crossing method, the so-called "dry method," involved building sandbag cofferdams to divert water around the construction area, digging the trench "dry," installing the pipe and then removing the cofferdams to restore water flow. The advantage of the dry method was a lower peak disturbance to the stream; the obvious drawback was a longer period of construction (days versus hours) and therefore a greater overall, or average, disturbance to the stream. While there had been some debate, and numerous visits to streams like Wappinger to evaluate the wisdom of wet versus dry crossings, FERC ultimately certificated a wet crossing method - and the NYPSC agreed. 
When construction crews reached Wappinger Creek in early September 1991, serious strains had already developed between Iroquois and its contractors on the one hand, and the NYPSC inspectors on the other. ${ }^{19}$ On numerous occasions before early September, at a number of small streams, the NYPSC inspectors had directed Iroquois and its contractors to switch from the FERC and NYPSC approved wet crossing method to the dry crossing method. Iroquois, not realizing what was ahead, had voluntarily complied with the NYPSC directions, in the interest of maintaining some semblance of good relations and, further, because at all of the subject streams, a dry crossing could be accomplished using an alternative dry method, called the "pump around" method. When all was said and done, Iroquois estimated that the cost of cooperating with the NYPSC in using "pump arounds" exceeded several million dollars.

At the first Wappinger Creek crossing in early September 1991, the NYPSC inspectors once again suggested that a dry crossing method be used in lieu of the approved wet crossing method. In the case of Wappinger Creek, however, the water flow and stream width made use of the pump-around method impossible. Thus, a dry crossing could only be accomplished using the cofferdam method, which would have required a change in both the FERC and NYPSC certifications. Accordingly, Iroquois refused to heed the NYPSC "suggestions" at the first and again at the second, Wappinger Creek crossings.

On September 9, 1991, as Iroquois' contractor was moving equipment to perform the third Wappinger Creek crossing, the NYPSC chief inspector formally requested that the third crossing be done using the dry method. Iroquois repeated its position that it could not use the cofferdam method without departing from the FERC certificate and in any event the stream was approved by both the FERC and the NYPSC for a wet crossing, which Iroquois estimated could be done, start to finish, the next day.

On the morning of September 10,1991, immediately before construction was to begin, the NYPSC again requested that Iroquois use the cofferdam dry crossing method. When Iroquois again refused, the on-site NYPSC inspector directed Iroquois to stop work at the crossing. Under Iroquois' Article VII certificate, a field inspector's ability to issue a "temporary stop work order" was limited to cases where the inspector observed an activity causing significant environmental harm "in clear violation of a [NYPSC] order." Even then, an NYPSC field stop work order merely triggered a mandatory consultation process but did not require Iroquois to stop work, for the simple reason that, under the doctrine of Federal preemption, only FERC could stop or modify work on the pipeline.

While the Iroquois supervisor on site was conferring with Iroquois headquarters and after calls had been placed by Iroquois' Vice President for Engineering and Construction to the chief NYPSC environmental official in Albany, DEC Environmental Conservation be penalized for 11 "incidents" involving such things as burning trees greater than four inches in diameter, jeopardizing a beaver dam, etc. Iroquois' response to the Order to Show Cause was that (a) the 11 alleged "incidents" were factually incorrect and (b) the NYPSC had no power to impose monetary penalties on Iroquois but instead must address any such complaints to FERC. Because of subsequent events, the Order to Show Cause proceeding essentially became academic. 
Officers ("ECOs"), joined later by State Police officers, arrived at the scene in squad cars and proceeded to arrest the Iroquois construction supervisor and five equipment operators engaged in trenching Wappinger Creek, charging them under felony statutes with "unauthorized discharges into the waters of the state." The six arrested men were searched, handcuffed and transported to jail, where they remained (in handcuffs) for more than five hours until a bail hearing could be held. The effect of the arrests was to stop work at the third Wappinger Creek crossing.

The extraordinary circumstance of state law enforcement officials arresting construction workers engaged in performing work for which Iroquois had a Federal license was unprecedented in the history of pipeline construction. To this day, there appears to be no explanation as to how governmental agencies with a patent understanding of the preemptive effect of Iroquois' FERC certificate could have done what they did. It is not even clear what officials within what agency authorized the arrests. Nonetheless, in the next two days, Iroquois initiated actions in Federal District Court against both the NYPSC and DEC, seeking declaratory orders that the state actions and the laws under which they were purportedly taken, were preempted. The lawsuits also sought injunctions against both agencies to prevent and preclude further disruptive actions. In light of the extreme gravity of the situation, Iroquois sought temporary restraining orders ("TROS") against both agencies and the Federal District Judge scheduled a hearing on the requests for TROs on September 12, 1991. Because no further construction activity was occurring at Wappinger Creek and because the NYPSC and DEC assured the Judge that no further punitive measures would be taken pending action by the Court, the Judge denied the TROs without prejudice and scheduled a further hearing on the TRO applications for one week later. Legal memoranda were due to be filed with the Court by 4:00 p.m. on September 17, 1991.

In such circumstances, the imminent threat of action by a court frequently results in settlement discussions in an effort to avert the permanent effects of a negative judicial declaration. Such was the case here. Moments before the 4:00 p.m. deadline on September 17, Iroquois informed the Judge that, based on discussions held to date, settlement appeared possible. After days of negotiations, Iroquois and the DEC reached a written settlement as of October 1, 1991. That settlement resolved the arrests by dropping all charges and effectively committed the DEC not to take enforcement action against Iroquois while Iroquois was engaged in construction of the FERC-certificated pipeline. Because, without DEC, the NYPSC had no power to interfere with construction by force, Iroquois also agreed to drop the request for a TRO against the NYPSC. The lawsuits in Federal court, however, remained pending, subject to further settlement discussions.

The Iroquois action against the DEC was eventually terminated by agreement of the parties pursuant to the written settlement reached as of October 1. Circumstances with the NYPSC were different, however. In an effort to resolve the NYPSC's substantive claim that the cofferdam dry crossing method was preferable at Wappinger Creek, FERC in conjunction with Iroquois, agreed to an experiment. The experiment was simple (albeit very costly). The next two sensitive stream crossings were immediately downstream of Wappinger Creek. FERC agreed that the NYPSC cofferdam dry crossing method would 
be utilized at one crossing (of the Roeliff Jansen Kill) and the previously authorized wet crossing would be used at the second crossing (the Ten Mile River).

The result of the experiment is now the subject of a public report by FERC/OPPR, issued on March 23, 1992. In short, the report concluded that NYPSC dry crossing method at Roeliff Jansen Kill was seriously detrimental to that stream. In contrast, the Ten Mile River wet crossing was accomplished with great speed and with minimal disruption to the stream. At the end of it all, Iroquois went back to Wappinger Creek and completed the crossing using the originally certificated wet crossing method (with the addition of extra silt curtains to assuage concerns of the NYPSC), the very method for which six construction workers had been incarcerated!

The Wappinger Creek Incident, and particularly the outcome of the experimental crossing, provided a window of relative calm during which pipeline construction was completed. The first segment of the pipeline, from the Canadian border to Wright, NY (near Albany) where it interconnected with Tennessee's line serving New England, was placed in service on December 1, 1991. The remainder of the line was placed in service, all the way to Long Island, on January 25,1992 . These in-service dates reflected a delay of nearly six weeks, caused in part by the events at Wappinger Creek.

\section{CONTINUATION OF THE FEDERAL LITIGATION AND THE COMMENCEMENT OF STATE LITIGATION}

Shortly before commencement of service to Long Island, the NYPSC and Iroquois agreed to make one last effort to settle outstanding issues between the parties. It was in the context of those settlement discussions that the legal positions of the parties and the nub of the Federal/state conflict, finally took shape.

In summary, the NYPSC's position was that Iroquois had violated provisions of the EM\&CPs and the Article VII certificate and that the NYPSC possessed the independent power, under state law, to "enforce" the provisions of those authorizations. By "enforcement," the NYPSC meant the power to impose monetary penalties. Thus, to the NYPSC, a "settlement" of the parties' differences meant the payment of money to the State of New York by Iroquois.

Iroquois' position on the law was that the NYPSC had no independent regulatory authority and therefore did not have the power to impose monetary penalties, or any other form of legal or equitable relief, on an interstate pipeline such as Iroquois. Iroquois' position in settlement was that, to the extent the construction process had not yet been completed (in that the right of way had not been fully restored), Iroquois would commit (and provide financial assurances) that the restoration work would be completed in accordance with the requirements of its FERC certificate. In addition, Iroquois was 
willing to provide further offsets ${ }^{20}$ to compensate for any lasting, site-specific environmental impacts which may have been caused by construction.

Given the obvious distance between the parties' positions, it was not surprising that settlement discussions were brief. On February 20, 1992, after a lengthy settlement meeting held on February 18, the NYPSC authorized its General Counsel to commence an action against Iroquois in state court seeking penalties for violations of state law. In the face of that action, Iroquois advised the Federal District Court on February 20, 1992 that the lawsuit filed against the NYPSC on September 12,1991 should be reactivated and filed an Amended Complaint updating the facts relevant to the Federal action. On February 24, 1992, the NYPSC lodged an action in state court against Iroquois and three of its contractors seeking $\$ 23.6$ million in penalties for violations of state law. The 136 count state complaint included counts for failure to "protect water quality" and failure to abide by the stop work order issued at the third crossing of Wappinger Creek, for which violation the NYPSC sought the sum of $\$ 400,000$. On the same day, the NYPSC moved to dismiss Iroquois' action in Federal District Court. On April 1, 1992, Iroquois moved to dismiss or stay the state penalty proceeding brought by the NYPSC and, on April 14, 1992, filed a crossmotion opposing the NYPSC's motion to dismiss Iroquois' Federal action and seeking summary judgment in Iroquois' favour. All of these pleadings, taken together, joined the issue of whether, in the face of a comprehensive Federal regulatory scheme governing interstate pipelines, the NYPSC retained independent power under state law to regulate, and penalize, an interstate pipeline for alleged violations of state orders (even where those state orders conflicted with Federal authorizations).

As this article was being written, the parties had once again deferred proceedings in the Federal and state litigation and were in the process of discussing settlement. In the meantime, the legal battlelines have been drawn and regardless of the outcome of settlement discussions, the positions of the parties may be instructive in future situations. The remainder of this article is devoted to a detailed summary of the legal principles advanced in Federal and state court and the (admittedly biased) conclusions of the author as to the appropriate outcome.

\section{FEDERAL PREEMPTION UNDER THE NATURAL GAS ACT AND THE RELATED ISSUES OF RETROACTIVITY, WAIVER AND ESTOPPEL}

The setting posed by the Iroquois Project brings the substance of the "Federal preemption" doctrine, as it relates to the Natural Gas Act and regulation of interstate pipelines, into clear focus. The Iroquois Project also brings into clear focus the strains placed on Federal/state relations when a Federally certificated interstate pipeline is 
constructed in the "back yards" of a state. Ordinarily, these Federal/state strains are managed by cooperation among Federal and state authorities and the constructor of the pipeline. But when large projects affecting thousands of landowners are at issue, the political pressure on states to "do something" becomes a major factor and when cooperation among authorities and certificate holders breaks down, it is paramount that the law provide a clear guide to implementation of the Federal certificate and construction of the pipeline.

In the case of the Iroquois Project, the issue was not whether the Natural Gas Act preempts state law with regard to construction of interstate pipelines. The Northern Natural and Schneidewind cases clearly establish that the Natural Gas Act preempts that field. Instead, the issue was whether, in light of the FERC requirement that Iroquois seek certain state permits and certifications (including the Federally-mandated certifications under the Clean Water Act and the Coastal Zone Management Act), and in light of Iroquois' "voluntary" submission to the NYPSC Article VII process, the state (specifically the NYPSC) acquired the independent power to regulate in the areas covered by the FERC-mandated state and local authorizations. When confronted with the fact that the Court of Appeals in National Fuel clearly resolved that issue against the retention of independent state power, the NYPSC resorted to the argument that the Court's declaration in National Fuel was prospective only, i.e., only applied to interstate pipelines permitted after the National Fuel decision was handed down. Further, the NYPSC argued that, even if National Fuel was not prospective only, Iroquois' application for, and acceptance of, the NYPSC Article VII certificate constituted a waiver of the preemptive effect of the Natural Gas Act or, alternatively, estopped Iroquois from challenging the NYPSC's right to enforce the Article VII certificate.

The NYPSC's position thus poses three discrete legal questions. Firstly, does the National Fuel decision have only a prospective effect where the statute (here, Article VII) preempted has already been "implemented" with regard to a particular project? Secondly, assuming that Federal preemption exists and is not prospective-only, can a party waive its preemption claim by applying for and accepting a state certificate? Thirdly, regardless of whether a party waived or intended to waive its preemption claim, can a party be estopped from raising its preemption claim by virtue of having accepted the "benefits" of a state certificate?

With regard to the issue of prospective application, the law is clear that, where a judicial determination is based on established precedent and an absence of compelling countervailing factors, there is no valid claim of non-retroactivity. The most recent U.S. Supreme Court case on the subject of the retroactivity of Constitutional decisions is James Beam Distilling Company v. Georgia. ${ }^{21}$ There, the Supreme Court stated. ${ }^{22}$

In the ordinary case no question of retroactivity arises. Courts are as a general matter in the business of applying settled principles and precedents of law to the disputes that come to bar. [citation omitted.]

22. $111 \mathrm{~S}$. Ct. at $2442-43$. 
Where those principles and precedents antedate the events on which the dispute turns, the court merely applies legal rules already decided, and the litigant has no basis on which to claim exception from those rules.

It is only when the law changes that in some respect that an assertion of nonretroactivity may be entertained, the paradigm case arising when a court expressly overrules a precedent upon which the contest would otherwise be decided differently and by which the parties may previously have regulated their conduct.

In National Fuel, the Court of Appeals firmly grounded its decision regarding the preemptive effect of the Natural Gas Act on Article VII in establishing precedent; it did not espouse a new rule of law. The Court of Appeals directly and explicitly followed the Supreme Court's prior decision in Schneidewind to conclude that FERC has exclusive jurisdiction over interstate pipeline facilities, and that the NYPSC's threat of fines against National Fuel was similar to the "imminent possibility of conflict" that led the Supreme Court to hold the Michigan statute in Schneidewind preempted. ${ }^{23}$ Schneidewind itself was decided on March 22,1988, nearly two years prior to the issuance of an Article VII certificate to Iroquois. The Court of Appeals also cited a long line of cases supporting the "imminent possibility of conflict" basis for preemption. ${ }^{24}$

More importantly, as the Court of Appeals noted in National Fuel, the preemption rule applied in that case is rooted in the Supremacy Clause of the Constitution, Article VI, clause $2 .{ }^{25}$ The prior history of the preemption rule is extensive, specifically as applied to the regulation of interstate natural gas pipelines. "The [Natural Gas Act] long has been recognized as a "comprehensive scheme of federal regulation of all wholesales of natural gas in interstate commerce." settled precedents to new and different factual situations, [and] no real question has arisen as to whether the later decision should apply retrospectively."27 Thus, the holding in National Fuel must be viewed, not as new law, but as the most recent pronouncement of the law on the issue of Federal preemption and the issue of whether the NYPSC has authority to enforce state laws that the Natural Gas Act preempts.

The statute at issue in Schneidewind was a state law requiring an interstate pipeline to obtain state authorization before issuing any securities. The Court held that the statute, because it related to "rates and facilities" of an interstate pipeline, was fully preempted by the Natural Gas Act. The fact that the Court did not draw a distinction between "rates" and "facilities" of interstate pipelines was specifically noted by the Court in National Fuel in applying Schneidewind to a statute affecting construction of interstate pipeline facilities. See Northern Natural, supra note 5, 372 U.S. 84 at 91-93, reh'g denied, 372 U.S. 960, 83 S. Ct. 1011, 10 L. Ed. 2d 14 (1963); National Steel Corp. v. Long, 680 F. Supp. 729, 738 (W.D. Mich, 1988), aff'd sub nom., Michigan Consolidated Gas Co. v. Panhandle Eastern Pipe Line Co., 887 F.2d 1295 (6th Cir. 1989), cert. denied, 494 U.S. 1079, 110 S. Ct. 1806, 108 L. Ed. 2 d 937 (1990). National Fuel, supra note 13 at 575.

26. Schneidewind, 485 U.S. 293 at 300 (quoting Northern Natural, 372 U.S. 84 at 91 ).

27. United States v. Johnson, 457 U.S. 537 at 549, 102 S. Ct. 2579 at 2586, 73 L. Ed. 2 d 202 (1982); accord Yates v. Aiken, 484 U.S. 21 1, 108 S. Ct. 534, 98 L. Ed. 2d 546 (1988). 
Notwithstanding the overwhelming evidence that National Fuel did not institute a new rule of law, the fact is that, even if it had, the application of the holding would still be retroactive, and not "prospective only" as the NYPSC argued. The U.S. Supreme Court has established, in Chevron Oil Co. v. Huson, ${ }^{28}$ the appropriate test governing when judicial decisions may be applied on a prospective basis only. Unless the explicit standards set forth in Chevron are met, the precedent in question must be given retroactive effect: ${ }^{29}$

\begin{abstract}
First, the decision to be applied nonretroactively must establish a new principle of law, either by overruling clear past precedent on which litigants may have relied, or by deciding an issue of first impression whose resolution was not clearly foreshadowed.... Second, it has been stressed that "we must... weigh the merits and demerits in each case by looking to the prior history of the rule in question, its purpose and effect, and whether retrospective operation will further or retard its operation."... Finally, we have weighed the inequity imposed by retroactive application, for "(w)here a decision of this Court could produce substantial inequitable results if applied retroactively, there is ample basis in our cases for avoiding the 'injustice of hardship' by a holding of nonretroactivity.
\end{abstract}

Under the Chevron test, the "prospective only" position of the NYPSC does not stand up. Clearly, as discussed above, National Fuel has not established a new rule of law. Further, even if National Fuel can be read to establish a new rule of law, the long line of consistent case law (i.e. Northern Natural and Schneidewind) interpreting the Supremacy Clause, foreshadowed the National Fuel result. Moreover, retrospective application of the National Fuel decision furthers, and does not retard, the operation of the preemption doctrine. Finally, retrospective application of National Fuel fails to produce inequitable results and in no way can be viewed as resulting in injustice or hardship. To the contrary, there was no serious question even prior to National Fuel of FERC's exclusive jurisdiction over interstate natural gas pipelines.

In the final analysis, application of the National Fuel decision to the Iroquois case is clearly in keeping with all relevant judicial precedent. ${ }^{30}$

A Court must apply the law as it exists at the time of its decision, even where the law has changed during the pendency of the action, unless the statute or legislative history reveals an intention of prospective application only, or retroactive application would lead to "manifest injustice."

National Fuel is clearly the law as it exists at this time. Nothing indicates that the court in National Fuel intended to apply the decision only prospectively, nor would retrospective application lead to "manifest injustice."

Interestingly, the judicial precedents set forth in the Federal cases on preemption and restated in National Fuel are also echoed in a New York state court decision, Skyview

28. 404 U.S. 97,92 S. Ct. 349, 30 L. Ed. 2 d 296 (1971) [hereinafter "Chevron"].

29. 404 U.S. at 106-107. (citations omitted).

3. Ames v. Merrill Lynch. Pierce, Fenner \& Smith Inc., 567 F. 2d 1174 at 1177 (2nd Cir. 1977) (citing Bradley v. Richmond School Bd., 416 U.S. 696 at 711, 94 S. Ct. 2006 at 2016, 40 L. Ed. 2d 476 (1974). 
Acres Coop., Inc. v. Public Serv. Comm'n of the State of N.Y.1 In that case, an interstate pipeline applied for FERC and NYPSC certificates to construct an extension of its interstate pipeline facilities. ${ }^{32}$ Prior to completion of the NYPSC proceeding, FERC issued a certificate authorizing construction. The interstate pipeline moved to terminate the NYPSC proceeding on the ground that FERC's jurisdiction over the pipeline was exclusive. The NYPSC denied the motion, holding that certain matters, including assessment of environmental impacts, remained within the jurisdiction of the NYPSC. The NYPSC proceeded to issue an Article VII certificate to the pipeline, approving a route identical to the route approved by FERC. In addition, under the Article VII provisions, the NYPSC also waived compliance with the zoning ordinance of a nearby town in order to permit construction of related metering facility, the relocation of which would have conflicted with the FERC authorization.

On appeal, the state court found that Federal preemption of state regulation of interstate pipelines extends to state approval of routing and state assessment of environmental matters. ${ }^{33}$ The court stated that FERC's environmental assessment is not subject to NYPSC modification; rather, the NYPSC's remedy is to intervene and participate in Federal proceedings along with other interested parties, precisely the position taken by Iroquois. The court did, however, properly uphold the NYPSC's waiver of local zoning ordinances, on the ground that such action was consistent with the Federal scheme of regulation pursuant to which the FERC relied upon state action to resolve potential conflicts between state (and local) and Federal law as a condition precedent to Federal certification of a project. Significantly, although Skyview Acres was decided after National Fuel, it both (i) applied National Fuel's precursor, Schneidewind, to find that "regulation of interstate gas pipelines is a matter within the exclusive jurisdiction of the FERC ${ }^{\prime \prime 4}$ thereby confirming that the preemption principle was well established even prior to National Fuel, and (ii) applied National Fuel retroactively to find the NYPSC preempted even as to an Article VII certificate issued prior to the National Fuel decision. Thus, Skyview Acres itself puts to rest any notion that there is a distinction between NYPSC action before, or after, National Fuel.

With regard to the NYPSC's position that, even if Federal preemption applied at the time the Article VII certificate was issued, Iroquois waived its claim of preemption or, alternatively, is estopped from asserting the claim, that the law is clear that a party cannot confer jurisdiction on a state which has otherwise been taken away by the Congress. National Fuel makes it clear that FERC has exclusive jurisdiction over the construction and operation of a Federally regulated interstate pipeline and that the Natural Gas Act has fully occupied that field. As a result, the NYPSC has no subject matter jurisdiction to regulate any interstate activities of interstate pipelines. Where subject matter jurisdiction does not exist, neither action taken by the parties, nor waiver or estoppel can confer such 
jurisdiction. In Insurance Corp. of Ireland v. Compagnie des Bauxites, the U.S. Supreme Court noted. ${ }^{35}$

...no action of the parties can confer subject matter jurisdiction upon a federal court. Thus, the consent of the parties is irrelevant, California v. Larue, 409 U.S. 109, 93 S. Ct. 390... (1972), [the] principles of estoppel do not apply, American Fire \& Casualty Co. v. Finn, 341 U.S. 6, 17-18, 71 S. Ct. 534, 541 $42 \ldots(1951)$, and a party does not waive the requirement by failing to challenge jurisdiction early in the proceedings.

This rule is equally applicable to agency jurisdiction. As stated by the Court in Plaquemine Port Harbor and Terminal District v. Federal Maritime Comm' ${ }^{36}{ }^{36}$ "[a]gency jurisdiction, like subject matter [jurisdiction] in the [F]ederal courts, cannot be achieved by consent of the parties."

In arguing that Iroquois waived its right to challenge the NYPSC's subject matter jurisdiction, the NYPSC (in its Federal court papers) relied on a single case, Public Service Commission v. Rochester Telephone. ${ }^{37}$ In that case, a New York state court found that Rochester Telephone, a utility clearly subject to NYPSC regulation, could not challenge the NYPSC's action for the first time on appeal. Aside from the fact that Iroquois was not challenging the NYPSC's action on appeal (which made Rochester Telephone inapposite in any event), the court in Rochester drew a clear distinction between a case where the utility challenging an agency action is clearly subject to the agency's jurisdiction, and a case where the challenging party is not subject to the agency's jurisdiction. Contrasting its holding with the decision in People ex rel. Utilities Commission v. City of Loveland, ${ }^{38}$ the Rochester Telephone court noted: ${ }^{39}$

Because the [City of Loveland's] challenge, based on an express prohibition in the Colorado Constitution, went to the jurisdiction of the commission, the court held that the city was not precluded by its failure to have sought a writ of review. In the case now before us, there can be no assertion of lack of jurisdiction, Rochester Telephone (a regulated public utility) being subject to the supervision of the agency and the order being one of a kind which the commission was empowered to issue under... the

456 U.S. 694 at 702, 102 S. Ct. 2099, 72 L. Ed. 2d 492 (1982). See also Adorno Enterprises v. Federated Deparment Stores, 629 F. Supp. 1565 at 1570 (D.R.I. 1986) "... subject matter jurisdiction either exists or it does not. And if the latter, it cannot be conferred by estoppel any more than it can be conferred by the consent of the parties"); Hamilton v. Bendrick, 313 N.Y.S. 2 d 860, at 862, 63 Mics. 2d 868 (1970) ("...subject matter jurisdiction cannot be conferred by consent or stipulation... or estoppel..."); New York v. Exxon, 697 F. Supp. 677 (S.D.N.Y. 1988).

838 F. 2d 536 at 542 n. 3 (D.C. Cir. 1988). See also United States v. LA. Tucker Truck Lines, 344 U.S. 33 at 38, 73 S. Ct. 67 at 69,97 L. Ed. 2d 54 (1952) (an order which is outside agency's jurisdiction is one that "even in the absence of timely objection... should be set aside as a nullity"); First American Bank v. Dole, 763 F. 2d 644 (4th Cir. 1985) (administrative agency's lack of power or jurisdiction not waived by failure to raise below); Railroad Yardmasters v. Harris, 721 F. 2d 1337 at 1338 (D.C. Cir. 1983 (same); Murray v. State Liquor Authority, 527 N.Y.S. 2d 384 (1988), aff. dismissed without op., 72 N.Y. 2d 951 (1988) (subject matter jurisdiction cannot be waived, may be challenged for the first time on appeal and need not be brought before administrative agency). 434 N.E. 2d 699, 55 N.Y. 2d 320, 449 N.Y.S. $2 d 463$ (1982).

38. 76 Col. 188, 230 P. 399 (1924) [hereinafter "City of Loveland"]. 
Public Service Law; at most, the inclusion of the challenged condition would represent only an excessive exercise of the authority vested in the commission.

The Iroquois case is on all fours with the facts of City of Loveland: the NYPSC has no authority over Iroquois under state law because Iroquois is a Federally regulated interstate pipeline which the NYPSC is not empowered to regulate.

The NYPSC's claim that Iroquois is estopped from raising its preemption claim has likewise been rejected by numerous courts. ${ }^{40}$ Accordingly, Federal courts have rejected arguments that parties were estopped from asserting subject matter jurisdiction challenges even when the parties had (i) taken a completely inconsistent position on jurisdictional issues earlier ${ }^{41}$ or (ii) already accepted benefits of a judgment that they subsequently challenged on jurisdictional grounds. ${ }^{42}$

In short, where the Congress has created a comprehensive scheme of Federal regulation through statutes which preempt the field, private parties (in this case, Iroquois) cannot, by their actions relative to third parties (in this case, the NYPSC) create jurisdiction in an non-Federal agency. Indeed, were the NYPSC correct that Iroquois could, as a matter of law, waive a claim of Federal preemption and thereby vest the NYPSC with authority to regulate an interstate pipeline, it would theoretically be possible for Iroquois to agree with the NYPSC on a pipeline route which conflicted with a route established by FERC. Such a result would clearly be invalid.

Even if it were possible in theory to waive a Federal preemption claim, Iroquois, of course, did no such thing. As noted above, Iroquois took great care along the way (starting with its application to the NYPSC and ending with its opposition to the motion to vacate its Article VII certificate) to make clear that its application and the resulting certificate were subject to Federal law and the overriding authority of the FERC certificate. Iroquois also took great pains to make clear that its only reason for seeking state permits and certifications was the Federal requirement that such permits be obtained as a condition precedent to Federal authorization to construct. Since waiver is the voluntary and intentional relinquishment of a known right or privilege, ${ }^{43}$ it is literally impossible to conclude that Iroquois knowingly waived its preemption claim.

While it may be true, in the abstract, that Iroquois received the benefits of a NYPSC Article VII permit, it is also impossible to conclude that Iroquois is estopped as a matter of law or fact from asserting the preemptive effects of Federal law in response to the

See Insurance Corp. of Ireland, supra note 35456 U.S. 694 at 702; Shirley v. Maxicare Texas, Inc. 921 F. 2d 565 at 568-69 (5th Cir. 1991); Von Dunser v. Aronoff, 915 F. 2d 1071 at 1074-75 (6th Cir. 1990); Long Island Radio Co. v. NLRB, 841 F. 2d 474 at 478 ; Rubin v. Buckman, 727 F. 2d 71 at 72 (3rd Cir. 1984); Pennsylvania, Dep't of Public Welfare v. U.S., 729 F. Supp. 1518 at 1522 (W.D. Pa. 1990), aff d without opinion, 915 F 2d. 1560 (3rd Cir. 1990).

41. Rubin, ibid. at 72; Pennsylvania, Dep't of Public Welfare, 729 F. Supp. 1518 at 1521-22.

42. Shirley, supra note $40921 \mathrm{~F} 2 \mathrm{~d} 565$ at 568-69.

43. 28 Am. Jur. 2d, Estoppel and Waiver, $\$ 154$ (1966 and Supp. 1991); Qualicare-Walsh, Inc. v. Ward, 947 F. 2d 823 (6th Cir. 1991); Martin v. Commercial Union Insurance Co., 935 F. 2d 235 (11th Cir. 1991); Pitts By and Through Pitts v. American Sec. Life Ins. Co., 931 F.2d 351 (5th Cir. 1991). 
NYPSC's efforts to impose millions of dollars in penalties. In order to establish that Iroquois is estopped in fact from asserting its preemption claim, the NYPSC would have the burden of proving: ${ }^{44}$

(1) Icjonduct which amounts to a false representation or concealment of material facts, or, at least, which is calculated to convey the impression that the facts are otherwise than, and inconsistent with those which the party subsequently attempts to assert; (2) intention, or at least expectation, that such conduct shall be acted upon by the other party; (3) knowledge, actual or constructive, of the real facts [;] [(4)] [a]s related to the party claiming estoppel,... [1]ack of knowledge and of the means of acquiring knowledge of the truth as to the facts in question; [(5)] reliance upon conduct of the party estopped; [and [6)] ...action based thereon of such a character as to change his position prejudicially.

Under the circumstances involved here and indeed under any imaginable circumstances where construction of interstate pipeline facilities is involved, the facts are directly contrary to those needed to establish estoppel under the Derry test.

\section{CONCLUSION}

In some respects, the fact that a project as large as Iroquois ruffled political and landowner feathers is not surprising. What is surprising is the fact that the State of New York and the NYPSC in particular, felt it necessary to challenge well-settled principles of Federal law to the extreme of the DEC and State Police arresting construction workers for performing Federally authorized work, in order to vindicate the opposition. The Court in National Fuel placed the problems associated with local opposition to pipeline project in proper perspective: ${ }^{45}$

The [NY]PSC concedes that just such delays [caused by state involvement] were visited upon amicus curie Columbia Gas Transmission Corporation in an Article VII proceeding concerning an interstate gas facility. It argues, however, that those delays were caused by extraordinary and exceptional local opposition. We perceive no reason to expect that local opposition will be an exceptional event, particularly because there may generally be little local benefit from interstate facilities.

The fact is that the Constitutional principles underlying the doctrine of Federal preemption make perfect sense in the context of projects, like the Iroquois Project, which affect interests going far beyond the interests of a single state. Indeed, the Iroquois Project illustrates, better than any hypothetical could, why it is critically important to maintain the doctrine of Federal preemption completely intact. For when there is even a small "chink" in the Federal protection afforded interstate gas pipeline projects, there is the danger that politics and emotions will turn the "chink" into a large crack. Certainly, the lawsuit by the NYPSC against Iroquois and its contractors for $\$ 23.6$ million in

Derry Finance N.V. v. Christiana Companies, Inc., 616 F. Supp. 544 at 549 (D.C. Del. 1985), aff d, 797 F. 2d 1210 (3rd Cir. 1986) (quoting State Bank of Albany v. Fioravanti, 70 A.D. 2d 1101, 418 N.Y.S. 2d 202 at 203-4 (3d Dept. 1979), aff d, 51 N.Y. 2d 638, 435 N.Y.S. 2d 947, 417 N.E. 2d 60 (1980)); Babylon Associates v. Coumty of Suffolk, 101 A.D. 2d 207 at 214, 475 N.Y.S. 2d 869 (2d Dept. 1984).

s5. Supra note 13 at 576 . 
penalties; the capital cost impact of state involvement in day-to-day construction decisions; and the economic and human impact of utilizing state criminal statutes and law enforcement authorities to control (and stop) Federally authorized work, make the case for strict interpretation of Congressional intent in imposing a comprehensive scheme of Federal regulation on interstate gas pipelines.

That is not to say that FERC would be well-advised to ignore state and local interests, as a means of protecting against a future Iroquois-type experience. Comity between Federal and state governments will always remain important. However, FERC has properly recognized the need for comity in making certain state and local permits necessary precedents to FERC certifications. In return, state and local governments must recognize that FERC's interest in cooperation is not tantamount to a transfer of jurisdiction or enforcement authority. For the scheme of comprehensive Federal regulation to work, jurisdiction and enforcement authority must remain in Federal hands, and state and local governments should recognize that, to the extent they or their citizens have a grievance, the remedy is through the Federal process, not through self-help. 